\title{
Being San in a developing and water-stressed Botswana
}

James G Workman: Heart of dryness: how the last Bushmen can help us endure the coming age of permanent drought (Walker and Company, New York, 2009). ISBN 978-0-8027-1558-6 Price \$27. pp. 321. Paperback, illustrations, index and bibliography. Referenced text.

Much of southern Africa's contemporary cultural history has a direct bearing on the manner in which natural resources have been exploited to secure a standing place for modernising states aspiring to sound governance on a continent that is, for many reasons, still reeling under the consequences of post-colonial positioning in a globalising world. In the title of this book the American journalist and writer, James G Workman, reminds us of the seminal novel of Joseph Conrad (1857-1924), The heart of darkness (1899) that defined the nature of colonialism in Africa. He takes it a step further and underlines, along with the current evolving post-colonial state of mind the major environmental crisis of the $21^{\text {st }}$ century - global warming.

The study is highly readable. Although it tends to border on popular journalism (aimed primarily at an American reading public) Heart of dryness is based on sound research on Botswana and the San (Bushman) people at a time when the country is still one of the exemplary and most successful democracies of Africa.

The book deals with a contemporary history of a group of San (Workman prefers to use the more familiar term 'Bushmen') in the Kalahari who were forced by the government of former president, Festus Mogae, to move out of the Central Kalahari Nature Reserve. They had been resident in the reserve since the 1960s - ironically also as a result of a relocation strategy devised by officials of the former British Bechuanaland Protectorate. The government's motivation for the more recent relocation plan has an ominous ring to it. It wanted to prepare the way for diamond mining operations in a highly water-stressed region -a long battle that the San have recently lost.

The heroine of Workman's history is the mater familia, Qoroxloo Duxee, whose life story is a primary source of the historical consciousness of a community of San. They are representative of some of the last living remnants of indigenous people who have been resident in Southern Africa since the late Stone Age.

When government officials started applying pressure to relocate the San to an area outside the reserve, Qoroxloo was at the helm of a group who refused to leave. She then took them further into one of the most arid parts of southern Africa's Kalahari Desert. She was instrumental in helping the community rediscover some of their ancient strategies of surviving under waterstressed circumstances. The plan was simply: revert back to customs devised by the ancestors over the past 10000 years when the region's copious surface water supplies started drying up. 
Workman, operating in a modernist mode, is well aware of current global trends in climate change. He looks at the San's way of life and sees that there are lessons to learn. These people were able to adjust to conditions that would typically be adverse to modern humans in the developed countries of the world. How the San could take the leap into the risky business of eking out an existence with boreholes no longer accessible, is of cardinal importance to the author. Ultimately he suggests San character and the will to maintain personal freedom in an environment with which they are historically familiar, are some of the attributes that made it possible.

At times the narrative is sentimental - perhaps with good reason. The San are people who have been persecuted by representatives and leaders of modern, and more recently also of modernising societies, in southern Africa. It has been an ongoing struggle for these often-misunderstood people since the $17^{\text {th }}$ century. Little wonder then that Workman resorts to a philosophical discourse on genocide when he discusses a human being's basic right to water as an extension of universal human rights. He convincingly argues that the Botswana government was at fault in its actions against the San.

Botswana's development syndrome gained momentum in the 1960s when the government of President Seretse Khama opted for mining and responsible governance with the objective to modernise one of Africa's newly independent states. The country had a small population. They could therefore be ruled effectively. One shortcoming in the development equation was the absence of sufficient water supplies. In an effort to satisfy the demand of the farming and mining industry for water, the government started using the latest in borehole drilling technology. It also invested in petroleum-powered water pumping technology. The source? Ancient subterranean lakes under the sands of the Kalahari had to satisfy the ever-increasing demand for one of southern Africa's finite natural resources. By the 1990s it was evident that the system was running awry. Large modern surface water storage dams constantly experienced problems with evaporation. Over-used boreholes started drying up. Furthermore, the cost of pumping the fossil water to the surface increased as a result of the energy crisis. At the same time the government had to contend with a growing socio-economic demand for more water to support the country's development.

Interestingly, Workman explains, it was under these circumstances that the San actually excelled. They were resilient and knew how to operate effectively under dry conditions. They could survive on food from the veld. Their technological arsenal of indigenous knowledge included the use of desert plants with a high water content, which they effectively used to still hunger and thirst. The author discusses some of the plants and their applications. Apart from also discursively contemplating the dietary qualities value of wild animal flesh, 'illegally' hunted by the San, he also describes the San's strategies of extracting subterranean supplies of water in what appears to be barren desert. The dietary habits of the San, the author suggests, can inform modern society in search of finding solutions to some if its ills. What is clear is that they are more than aware of the value of water. They would go to great lengths to procure supplies. They are also more than able to maintain their inherent resilience when the authorities intervene and prevent them from access to water they fetched over distances of several hundred kilometres.

Although he is supposedly an independent journalist, Workman, is clearly sucked into the San's struggle for survival. From the outset it is evident that he actively tries to win their confidence. He wants to know more about them. Then, he gradually drifts into becoming an activist. This is evident in his strategies to subvert the Botswana government's discourses aimed at legitimising its actions against the San. Workman draws comparisons between the past and the present. He 
reads and communicates with the leading experts on Botswana and its oldest residents. Simultaneously he is absorbed in the approaching global water crisis that is unfolding as a result of climate change. It is in this context he brings some of the most up to date perspectives of issues in the global water sector to southern Africa. It is as if the Stone Age meets Global Warming, with modernity and its virtual sense of reality as a catalyst. This approach is informative and provides a familiar and comfortable framework for readers who are less informed on the contemporary history of the subcontinent.

The author deals with the complexity of maintaining democratic governance in a modernising state. Botswana's government, under Mogae, he explains, tended to resort to certain totalitarian strategies of governance. This was evident in its dealing with the San. Workman clearly points this out and discusses the issue in a variety of dimensions. He spells out an important principle: "We don't govern water; water governs us" (p. 242). The San, in their struggle with the government of Botswana, were aware of this principle. The government only learnt that lesson when the trappings of modern technology proved to be futile in their quest to satisfy the growing demand for water.

Workman's narrative strategies are cunning. He explains how the ancient technologies of the San - from water storage to sanitation - can be of relevance to some of the water-related problems we currently try to address with a myriad of futile experimental strategies. The reader is also challenged to reconsider some of the material values of modern society. For example, how do you compare the value of diamond jewellery (because diamonds will last forever), with beads made of fragments of ostrich egg-shell (by a threatened people)? Or, how necessary are some of the everyday uses of water in modern society? The author is clearly informed on Botswana's politics. He is also aware of some critical issues of the country's economy and the importance of responsible approaches to development. With these insights and other insights, he eloquently informs us about a small unique society - probably one of the last of its kind - representative of Africa's early culture.

Johann Tempelhoff

North-West University (Vaal)

TD, 6(1), July 2010, pp. 287 - 289. 